畹 


\section{Progress in Inflammation Research}

\section{Series Editor}

Prof. Dr. Michael J. Parnham

PLIVA

Research Institute

Prilaz baruna Filipovica 25

10000 Zagreb

Croatia

\section{Forthcoming titles:}

Migraine: a Neuroinflammatory Disease? E.L.H. Spierings, M. Sanchez del Rio (Editors), 2002

Mechanisms and Mediators of Neuropathic Pain, A.B. Malmberg, S.R. Chaplan (Editors), 2002

The Hereditary Basis of Allergic Diseases, J. Holloway, S. Holgate (Editors), 2002 Bone Morphogenetic Proteins: From Laboratory to Clinical Practice, S. Vukicevic, K.T. Sampath (Editors), 2002

(Already published titles see last page.) 
NMDA Antagonists as Potential Analgesic Drugs

Dalip J. S. Sirinathsinghji

Ray G. Hill

Editors

Springer Basel AG 
Editors

Dalip J.S. Sirinathsinghji

Ray G. Hill

Merck, Sharp \& Dohme Research Laboratories

Neuroscience Research Centre

Terlings Park, Harlow

Essex CM20 2QR

UK

A CIP catalogue record for this book is available from the Library of Congress, Washington D.C., USA

Deutsche Bibliothek Cataloging-in-Publication Data

NMDA antagonists as potential analgesic drugs / D. J. S. Sirinathsinghji ;

R. G. Hill ed.. - Basel ; Boston ; Berlin : Birkhäuser, 2002

(Progress in inflammation research)

ISBN 978-3-0348-9453-1 ISBN 978-3-0348-8139-5 (eBook)

DOI 10.1007/978-3-0348-8139-5

The publisher and editor can give no guarantee for the information on drug dosage and administration contained in this publication. The respective user must check its accuracy by consulting other sources of reference in each individual case.

The use of registered names, trademarks etc. in this publication, even if not identified as such, does not imply that they are exempt from the relevant protective laws and regulations or free for general use.

\section{ISBN 978-3-0348-9453-1}

This work is subject to copyright. All rights are reserved, whether the whole or part of the material is concerned, specifically the rights of translation, reprinting, re-use of illustrations, recitation, broadcasting, reproduction on microfilms or in other ways, and storage in data banks. For any kind of use, permission of the copyright owner must be obtained.

(C) 2002 Springer Basel AG

Originally published by Birkhäuser Verlag in 2002

Softcover reprint of the hardcover 1st edition 2002

Printed on acid-free paper produced from chlorine-free pulp. TCF $\infty$

Cover design: Markus Etterich, Basel

Cover illustration: Molecular structure of the NMDA receptor (see p. 9)

ISBN 978-3-0348-9453-1 


\section{Contents}

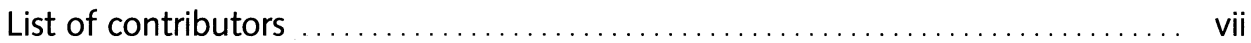

Dalip J.S. Sirinathsinghii and Ray G. Hill

Introduction .....................................................

Tony Priestley

Pharmacology and electrophysiology of excitatory amino acid receptors

Michael Rigby, Robert P. Heavens, David Smith, Ruth O'Donnell,

Ray G. Hill and Dalip J.S. Sirinathsinghii

Distribution of NMDA receptors in brain and spinal cord

Michael J. Cumberbatch, Boris A. Chizh and P. Max Headley

Spinal nociceptive processing: NMDA receptors and modulation

by neuropeptides

Qing-Ping Ma and Clifford J. Woolf

The NMDA receptor, pain and central sensitization

Stéphanie Le Guen, Victoria Chapman and Jean-Marie Besson

Some pharmacological aspects of NMDA-mediated nociceptive transmission in the rat spinal cord as revealed by c-fos immunocytochemistry

Anthony H. Dickenson and Fiona C. Taylor

Interaction of NMDA and other neurotransmitter receptor systems in modulation of nociception

Susan Boyce and Nadia M.J. Rupniak

Behavioural studies on the potential of NMDA receptor antagonists as analgesics 
Christine N. Sang

Clinically available glutamate receptor antagonists in neuropathic pain states

Dalip J.S. Sirinathsinghii and Ray G. Hill

Future prospects for improved analgesic therapy

Index 


\section{List of contributors}

Jean-Marie Besson, INSERM U 161 and EPHE, 2, rue d'Alésia, 75014 Paris, France; e-mail: besson@broca.inserm.fr

Susan Boyce, Merck, Sharp \& Dohme Research Laboratories, Neuroscience Research Centre, Terlings Park, Harlow, Essex CM20 2QR, UK;

e-mail: susan_boyce@merck.com

Victoria Chapman, School of Biomedical Sciences, E Floor, Medical School, Queen's Medical Centre, Nottingham NG7 2UH, UK;

e-mail: victoria.chapman@nottingham.ac.uk

Boris A. Chizh, Grünenthal GmbH, Research and Development, Zieglerstrasse 6, 52078 Aachen, Germany

Michael J. Cumberbatch, Merck, Sharp \& Dohme Research Laboratories, Neuroscience Research Centre, Terlings Park, Harlow, Essex CM20 2QR, UK;

e-mail: michael_cumberbatch@merck.com

Anthony H. Dickenson, Department of Pharmacology, University College, Gower Street, London WC1E 6BT, UK; e-mail: anthony.dickenson@ucl.ac.uk

P. Max Headley, Department of Physiology, School of Medical Sciences, University Walk, Bristol BS8 1TD, UK; e-mail: max.headley@bristol.ac.uk

Robert P. Heavens, Merck, Sharp \& Dohme Research Laboratories, Neuroscience Research Centre, Terlings Park, Harlow, Essex CM20 2QR, UK;

e-mail: robert_heavens@merck.com

Ray G. Hill, Merck, Sharp \& Dohme Research Laboratories, Neuroscience Research Centre, Terlings Park, Harlow, Essex CM20 2QR, UK;

e-mail: hill@merck.com 
Stéphanie Le Guen, INSERM U 161 and EPHE, 2, rue d'Alésia, 75014 Paris, France; e-mail: leguen@broca.inserm.fr

Qing-Ping Ma, Merck, Sharp \& Dohme Research Laboratories, Neuroscience Research Centre, Terlings Park, Harlow, Essex CM20 2QR, UK;

e-mail: qingping_ma@merck.com

Ruth O’Donnell, Merck, Sharp \& Dohme Research Laboratories, Neuroscience Research Centre, Terlings Park, Harlow, Essex CM20 2QR, UK;

e-mail: ruth_o'donnell@merck.com

Tony Priestley, Schering-Plough Research Institute, 2015 Galloping Hill Road, Kenilworth, NJ 07033, USA; e-mail: tony.priestley@spcorp.com

Michael Rigby, Merck Sharp \& Dohme Research Laboratories, Neuroscience Research Centre, Terlings Park, Harlow, Essex CM20 2QR, UK;

e-mail: michael_rigby@merck.com

Nadia M.J. Rupniak, Merck, Sharp \& Dohme Research Laboratories, Neuroscience Research Centre, Terlings Park, Harlow, Essex CM20 2QR, UK;

e-mail: nadia_rupniak@merck.com

Christine N. Sang, Department of Anaesthesia and Critical Care, Massachusetts General Hospital, 55 Fruit Street, Clinics, Boston, MA 02114, USA;

e-mail: Csang@partners.org

Dalip J.S. Sirinathsinghji, Merck, Sharp \& Dohme Research Laboratories, Neuroscience Research Centre, Terlings Park, Harlow, Essex CM20 2QR, UK e-mail: dalip_sirinathsinghji@merck.com

David Smith, Merck, Sharp \& Dohme Research Laboratories, Neuroscience Research Centre, Terlings Park, Harlow, Essex CM20 2QR, UK;

e-mail: david_smith@merck.com

Fiona Taylor, Department of Pharmacology, University College, Gower Street, London WC1E 6BT, UK

Clifford J. Woolf, Neural Plasticity Research Group, Department of Anesthesia and Critical Care, Massachusetts General Hospital and Harvard Medical School, Boston, MA 02129, USA; e-mail: woolf@etherdome.mgh.harvard.edu 